\title{
April 2014: Editorial
}

Jan Turek, Czech Institute of Egyptology, Charles University, Prague, Czech Republic

E-mail: turekjan@hotmail.com

Cristóbal Gnecco, Universidad del Cauca, Popayán, Colombia E-mail: cgnecco@unicauca.edu.co

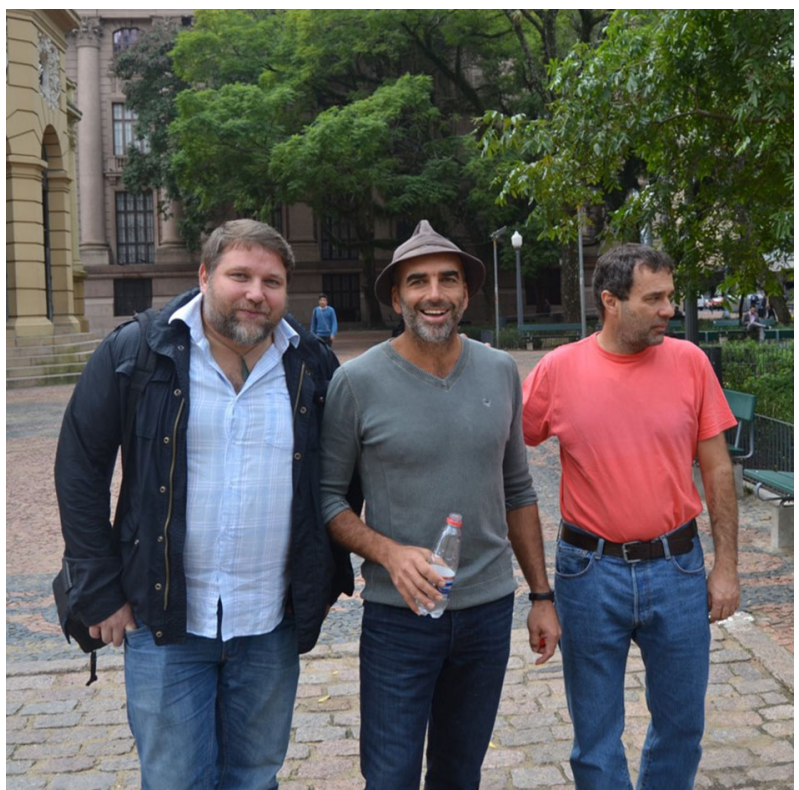

Editors of Archaeologies in Porto Alegre, June 2013. From left: Jan Turek, Nick Shepherd \& Cristóbal Gnecco

The world repeats itself, ceaselessly. Once again we witness social injustice, sectarian violence and cultural or ethnic dominance. The new imperialism threatens us all by dragging the world into a new Cold War. Aggression instead of political negotiation and intercultural understanding is yet again creating borders between people and their lives.

In such a fragile social and political context, we strongly believe that the militant role of Archaeologies is as powerful now as it used to be at the time of its origin. An important part of our agenda is to take an active part in shaping the archaeological discussion, bringing up different views, maintaining discussions, and helping to create a non-hierarchical and fair 
world. In this renewed task, we welcome the new editorial board, representing people from all over the world but having in common a social and political commitment that translates into a creative imagination of different post-national societies.

We take the occasion to thank the outgoing members of the previous board for their support that helped to shape the journal's editorial policies and academic prestige. In this regard, we have gained a significant international impact: we are now referenced in the ISI Arts and Humanities Citation Index and have been rated " $\mathrm{A}$ " in the Australian Research Council Humanities and Creative Arts journal index (SCImago Journal and Country Rank (SJR) 2011). 